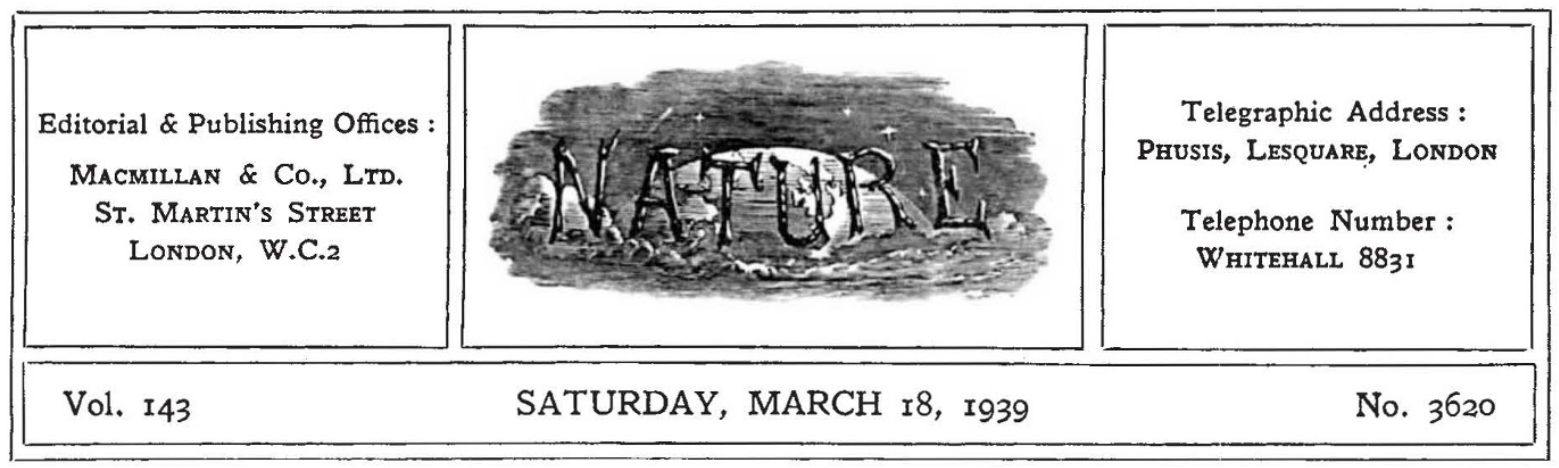

\title{
Organization and Development of Museums
}

$\mathrm{I}^{\mathrm{T}}$ is keeping within the truth to say that in Great Britain and Ireland a new museum is born every three weeks, roughly twenty in a year, or two hundred since Sir Henry Miers's report to the Carnegie United Kingdom Trustees was published in 1928. That is an index to the enthusiasm of groups of people aware that there are hidden things the public ought to see; but, alas, it is no index to the foresight of the enthusiasts, for the history of museums indicates that many of the new foundations, without endowments or any guarantee of permanent backing, will sooner or later drop out of the running and disappear. The death-rate of museums all but keeps up with the birth-rate; but the spectacle of the lingering death of the idea embodied in a collection which has outlived its interest does infinite harm to the museum movement.

Museums die because the people do not want them, at any rate in the form which their presentation too often takes; and if only the secret of a live interest could be discovered, and the discovery were rigidly and universally applied, a new page would be opened in the museum story. A great contribution towards this end is made in S. F. Markham's recent report to the Carnegie United Kingdom Trustees*, a book which ought to be pondered over by everyone interested in the present condition and potential future of the museums and art galleries of Great Britain.

The origin of the report is of historic interest. Ten years ago, Sir Henry Miers wrote the first thorough-going account of the museums of Great Britain, also for the Carnegie United Kingdom

* A Report on the Museums and Art Galleries of the British Isles (other than the National Museums), by S. F. Markham. Pp. iii $+179+$ 24 plates. (Dunfermline: Carnegie United Kingdom Trust, 1938).
Trustees, and having exhibited the pitiful shortcomings of the museum service, which in his opinion required complete reformation, he made suggestions for improvement along three linesby individual effort on the part of museum authorities, by co-operation, and by the helping hand (or purse) of external bodies. Anyone who takes the slightest interest in these public institutions must be aware of the stimulus Sir Henry Miers's investigation gave to the museum movement and the progress in certain directions made during the decade which has elapsed.

Mr. Markham acted as secretary to Sir Henry Miers; he has since carried out a survey of museums in most of the British Dominions and Colonies and in India, on behalf of the Carnegie Corporation of New York; so that no one could have been better equipped for the new British survey which the trustees desired to make, in order to assess the progress of the past ten years and to foreshadow the needs of the future.

Many years ago (1889), Sir William Henry Flower, in his presidential address at Newcastle-on-Tyne to the British Association for the Advancement of Science, defined the purposes of a museum as the advance or increase of knowledge in some given subject, and the diffusion of knowledge among the interested public-in short, the two aims of research and instruction. Half a century has seen great developments in museum standards, but the aims remain essentially the same. The first great purpose is to collect and conserve objects of historic, scientific or artistic importance for our own and future generations ; there follows the furthering of specialized knowledge by research in these collections, the more recent and very 
insistent aim of the education of the people by attractive exhibits, and the ultimate ideal of stimulating love of beauty or endeavour in some branch of human achievement.

Every museum cannot compass all these objects, but every museum must set out with its objective clearly conceived and must bend its activities to the accomplishment of its particular goal. But the goal is never attained. The essence of museum. success-even of museum existence-is perpetual striving and continuous progress. The only type of museum which can afford to remain static is that devoted to perpetuating the memory of a great personage-Shakespeare, Livingstone, Wolfe, to mention recent examples-where personal relies are bound to be limited in number, and where the attraction is predominantly emotional rather than educational. These, however, form a relatively small proportion of Great Britain's museums : of our eight hundred museums, "about 165 are devoted to a historical or personal theme, 100 to natural history alone, about 80 to art, 20 to medicine, and 20 to industry. The remainder, therefore, totalling some 400 museums, are general in their character, though many, probably 150 , have a distinct emphasis upon illustrating their immediate environment" (p. 52).

Sir William Flower wisely said, in the address referred to, "A museum is like a living organismit requires continual and tender care. It must grow, or it will perish." We would prefer to say 'develop' rather than 'grow', for there is an impression that the addition of new rooms always means progress, whereas extensions may actually hinder the development constantly required in any collection. But the plain fact is that museums die (and we know of collections excellent in their day, and their day opened nearly a century ago, disappear in recent years) because they have become moribund-activity, the breath of life, has departed from them long ago.

The first essential for a developing museum (and all others are moribund) is a competent curator, who has the knowledge, the skill and the brains to plan and execute; and a competent curator deserves his reward-he may at least expect a living wage. Yet, apart from a hundred and forty out of more than eight hundred museums in Great Britain, "in nearly every other case the curator is paid a scandalously low salary". There are pitiful examples mentioned by Mr. Markham of salaries of $£ 50$ recently raised to $£ 75$ or to $£ 100$ a year. The County Borough of West Ham (population
294,000 ) offered $£ 155$ per annum for "a full time assistant with biological training, knowledge of photography, and a Science degree (not essential)" ; the County Borough of Reading (population 100,000) advertised for "a male assistant with practical Museum and Art Gallery experience, not under 22 and preferably registered for the Diploma, salary offered £115". And the London County Council pays its dust-collecting gangers $£ 158$ and its dustmen $£ 150$ a year! Is it surprising that dust accumulates and men and ideas decay in some of the provincial museums?

The ten years which have passed since Sir Henry Miers made his recommendations have emphasized the backwardness of the weaker museums (nearly four hundred and fifty in number), since the better institutions have taken advantage of new opportunities and have pushed ahead. There is closer co-operation between them, expressed in flourishing regional federations, and in the growing power of the Museums Association; they have been aided and advised to a greater extent by the national museums; and they have made more use of the development of exhibition technique, to the great benefit and the educational value of their halls and galleries.

The increasing museum contribution to education in progressive institutions has indeed been one of the impressive features of this century. Not only have greater efforts been made to replace dull collections by displays in which art and science blend for the attraction and instruction of the public, but a deliberate attack upon indifference has also begun. Temporary exhibits of objects of particular interest, special exhibitions illustrating achievements of, or developments in, art and science, the increasing use of modern methods of publicity, in which the newspapers have proved loyal helpers, the encouragement of regular school visits, and the circulation of loan collections among schools-all these devices have become part of the recognized services of museums to the public ; and the public has responded by showing a new and increasing interest in museums.

But something still is lacking. Efforts tend to be spasmodic and confined to comparatively few centres; improvements are costly, and municipalities and private bodies are already hard put to it to find the funds required, even if they were sure of the most desirable lines of advance; and there are museums that are static, because no interest is taken in them. If the country's museums over all are to be made worthy of the 
great purposes which it is in their power to serve, some beneficent deus ex machina must appear to weld the scattered units into a national movement. Whether that kindly guiding power shall be vested in a Government department, or shall emerge from the museums themselves by way of the Museums Association, it is essential that it should have two basic functions: first, that of giving advice where advice is sought, and of making recommendations where museums are moribund, and secondly, that of subsidizing improvements and encouraging developments by the use of moneys allocated by Government for museum purposes:

So, as Mr. Markham says: "In the mind's eye one can see organised throughout the length and breadth of the country temples of vision, where young enthusiasts will find a ready welcome and a helping hand with a colossal book of knowledge ; schools will have auxiliaries on the cultural side not less than those which playing-fields now give them on the physical side, and adults will find in these centres a combination of relaxation, interest, and ever-widening horizons."

\section{The Scientific Work of Charles Fabry}

\section{CEuvres Choisies}

Par Charles Fabry. Publiées à l'occasion de son jubilé scientifique. Pp. vi+695. Jubilé scientifique de M. Charles Fabry célébré à la Sorbonne le 3 décembre 1937. Pp. 96. (Paris: Gauthier-Villars, 1938.)

WHEN, in 1937, Charles Fabry retired from his professorship in the University of Paris, he was persuaded to arrange and edit his principal scientific papers. The "CEuvres Choisies" is the result.

It is an impressive record, not so much from the actual amount of reading matter, though that is considerable, but because the author by selection and compression has been able to present an adequate record of the main results of half a century's research in about two hundred and fifty thousand words.

Before we attempt to summarize the contents of the book, let it be said at once that Fabry's love of research was accompanied by a devotion to teaching. $\mathrm{He}$ has said himself: "Toute mon existence a été consacrée à la Science et à l'enseignement, et ces deux grandes passions m'ont procuré les plus vives joies." There are, perhaps, not many teachers who could refer to their vocation with such enthusiasm; but all would agree that it is a great consumer of time and energy. In assessing the magnitude of Fabry's work one must read between the lines of his paper a story of tireless activity as an inspiring and greatly loved teacher.

To return to Fabry's "CEuvres Choisies". He was only about twenty years old when he took a post at the Faculté des Sciences at Marseilles under Macé de Lépinay. It was not long before the two published in collaboration a paper on the "Theorie générale de la visibilité des franges d'interférence" (1891). Thus early the keynote was struck which was to echo through so much of Fabry's work-more than half the book is concerned with the phenomenon of the interference of light and its application to the solution of physical problems.

About five years later, Fabry commenced to study the interference fringes of silvered plates in collaboration with A. Perot, and in 1897 they published the first important description of the Fabry-Perot type of interference fringes and their use in the measurement of length.

This was the type which Fabry always used thereafter, its advantage lying in the much greater fineness of the fringes as compared with those used, for example, by Michelson.

In a series of papers, Fabry and Perot described the properties of these fringes; how to determine the number of the order of a fringe corresponding to a large path difference, how to use them for the measurement of lengths up to several decimetres, and for the comparison of wave-lengths of different rays (1898 and 1899). They then applied the method to determine the size of a $4 \mathrm{~cm}$. cube of quartz in wave-lengths of cadmium red light, and with Macé de Lépinay determined by its aid the mass of a decimetre of water. Other papers on interference metrology finally led, in 1907, to the epoch-making "Nouvelle détermination du mètre en longueurs d'ondes lumineuses" and the "Détermination de la longueux d'onde de la raie rouge du Cadmium".

This determination led to Benoit, Fabry and Perot making, in 1907, at the Conference of the International Union for Co-operation in Solar Research at Meudon, the following recommendation: "La longueur d'onde de la raie rouge de la lumière 